ACCELERATION AND IMPROVEMENT OF PROTEIN IDENTIFICATION BY MASS SPECTROMETRY 


\section{Acceleration and Improvement of Protein Identification by Mass Spectrometry}

Edited by

WILLY VINCENT BIENVENUT

Biochemistry Institute, Protein Analysis Facility,

Lausanne University, Switzerland

䌼 Springer 
A C.I.P. Catalogue record for this book is available from the Library of Congress.

ISBN 1-4020-3318-4 (HB)

ISBN 1-4020-3319-2 (e-book)

Published by Springer,

P.O. Box 17, 3300 AA Dordrecht, The Netherlands.

Sold and distributed in North, Central and South America

by Springer,

101 Philip Drive, Norwell, MA 02061, U.S.A.

In all other countries, sold and distributed

by Springer,

P.O. Box 322, 3300 AH Dordrecht, The Netherlands.

Printed on acid-free paper

All Rights Reserved

(C) 2005 Springer

No part of this work may be reproduced, stored in a retrieval system, or transmitted in any form or by any means, electronic, mechanical, photocopying, microfilming, recording or otherwise, without written permission from the Publisher, with the exception

of any material supplied specifically for the purpose of being entered and executed on a computer system, for exclusive use by the purchaser of the work.

Printed in the Netherlands. 
"Conformity is the jailer of freedom and the enemy of growth."

John F. Kennedy

\section{DEDICATION}

To my parents for their help and support during all the years. 


\section{TABLE OF CONTENTS}

TABLE OF CONTENTS

vii

PREFACE

ACKNOWLEDGEMENT

LIST OF CONTRIBUTOR
XVii

xix

$\mathrm{xxi}$

\section{CHAPTER 1}

\section{WV. Bienvenut}

Introduction: Proteins analysis using mass spectrometry 1

1. Introduction: from genome to proteomic analysis 1

2. Proteins separation 3

2.1. Introduction 3

2.2. Electrophoretical separation 3

2.2.1. Gel separation 4

2.2.1.1. Molecular mass separation 5

2.2.1.2. Isoelectric focalisation separation technique 5

2.2.1.3. Bi-Dimensional separation technique 6

2.2.1.4. Visualization/staining methods for gel separated proteins 6

Organic dyes $\quad 7$

Metallic ions staining $\quad 9$

Covalently immobilized dyes 10

Radioisotope labelling $\quad 11$

2.2.2. Capillary electrophoresis separation $\quad 11$

$\begin{array}{ll}\text { 2.3. Liquid chromatography } & 12\end{array}$

2.4. Mutidimentional chromatography separation 14

$\begin{array}{ll}\text { 2.5. Conclusion } & 14\end{array}$

3. Proteins electroblotting from gel to polymere membrane 14

$\begin{array}{ll}\text { 3.1. Introduction } & 14\end{array}$

3.2. Transfer systems 15

3.3. Composition and influence of the blotting buffer and solvents 18

$\begin{array}{ll}\text { 3.3.1. Buffers composition } & 18\end{array}$

3.3.2. Effects of the SDS and methanol contained in the buffer solution 20

3.3.3. Others influencing parameters 20 
viii

$\begin{array}{ll}\text { 3.4. Membranes staining } & 21\end{array}$

3.4.1. Non-denaturing organic staining process 21

3.4.2. Radiolabelled protein detection 23

3.4.3. Denaturing staining process 24

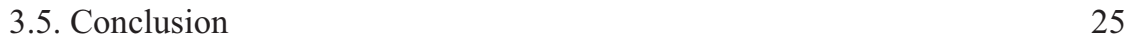

4. Proteins identification 25

4.1. Introduction 25

4.2. Nuclear proteins identification procedures 25

$\begin{array}{ll}\text { 4.3. Enzymatic cleavage of proteins } & 27\end{array}$

$\begin{array}{ll}\text { 4.3.1. Introduction } & 27\end{array}$

$\begin{array}{ll}\text { 4.3.2. Enzymatic cleavage description } & 27\end{array}$

4.3.2.1. Treatment and digestion of transblotted proteins 28

4.3.2.2. Treatment and digestion of gel separated proteins 28

4.3.2.3. Utilisation of immobilized endoproteinases 29

$\begin{array}{ll}\text { 4.3.3. Trypsin } & 29\end{array}$

4.3.3.1. Enzymatic activity measurement 31

$\begin{array}{ll}\text { 4.3.3.2. Cleavage specificity } & 31\end{array}$

4.3.4. Endoproteinase Lys-C 33

4.3.5. Chymotrypsin 34

4.3.6. Pepsin $\quad 35$

4.3.7. Bacterial endopeptidases $\quad 36$

$\begin{array}{ll}\text { 4.3.8. Conclusion } & 37\end{array}$

$\begin{array}{lll}4.4 & \text { Chemicals cleavage of the proteins. } & 37\end{array}$

4.4.1. Introduction 37

$\begin{array}{ll}\text { 4.4.2. Acidic hydrolysis } & 37\end{array}$

4.4.3. Cyanogen bromide 38

4.4.4. Cleavage at the carbonyl side of t he Trp 38

4.4.5. Cleavage at Cys residues $\quad 40$

4.4.6. Conclusion $\quad 40$

4.5. Sample preparation and clean-up for MALDI-MS analysis 41

4.5.1. Chromatographic treatment 41

4.5.2. Preparation of Samples for MALDI-MS analysis 42

4.5.2.1. Dry droplet method $\quad 42$

4.5.2.2. Spin-coated drying $\quad 43$

4.5.2.3. Slow crystallisation 43

4.5.2.4. Fast evaporation method 43

4.5.2.5. Crystalline germ method 44

4.5.2.6. Sprayed matrix $\quad 44$

4.5.3. Sample desalting procedures $\quad 44$

4.5.4. Conclusion $\quad 45$ 
4.6. Proteins identification using mass spectrometry 45

4.6.1. Protein identification using PMF technique. 46

4.6.1.1. Method description $\quad 46$

4.6.1.2. MALDI-TOF-MS analysis technique 47

The laser $\quad 47$

The matrix 49

The co-matrix $\quad 55$

4.6.1.3. MALDI ionisation mechanism $\quad 55$

4.6.1.4. Time of flight separation of the ions and its improvement 58

4.6.1.5. Signal detection and data acquisition $\quad 59$

4.6.1.6. Separation and detection using ICR-FT 59

4.6.1.7. Signal reproducibility $\quad 60$

4.6.1.8. Suppression effects $\quad 60$

4.6.1.9. Quantification by mass spectrometry 63

4.6.1.10. Data treatment for protein identification 65

MALDI-MS spectrum calibration $\quad 65$

Identification tools 66

Principal affecting factors during data processing $\quad 67$

Other possible criteria for protein Identification not directly integrated to identification tools $\quad 72$

Interpretation of results and limits of validity $\quad 72$

4.6.2. Protein identification from internal peptide sequence 73

$\begin{array}{ll}\text { 4.6.2.1. Introduction } & 73\end{array}$

4.6.2.2. ESI-MS/MS analysis $\quad 75$

5. Advances techniques for protein identification $\quad 79$

$\begin{array}{ll}\text { 5.1. Introduction } & 79\end{array}$

5.2. Chemical modifications $\quad 80$

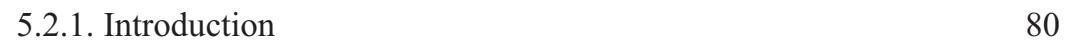

5.2.2. Reaction involving free amino groups of the peptides/proteins $\quad 80$

5.2.2.1. Acetylation of the amino groups $\quad 80$

5.2.2.2. Lys specific reactions 81

5.2.2.3. Iso-thiocyanate treatment of the free amino groups for $\mathrm{N}_{\text {-Ter }}$ cleavage (Edman type reaction)

5.2.3. Reaction involving free carboxylic groups of the peptides/proteins 84

5.2.4. Labile hydrogen atoms exchange to deuterium atoms 85

5.2.5. Cysteine alkylation 86

5.2.6. Peptides modification using charged modifications 87

5.2.6.1. Positively charged modifications $\quad 87$

5.2.6.2. Negatively charged modifications $\quad 88$

5.2.6.3. Conclusion $\quad 89$

5.2.7. Stable isotope labelling during the digestion 89

5.2.8. Conclusion 90 
5.2. Biochemical approach 91

5.3. In-vivo labelling 94

6. Automated approach 94

\section{CHAPTER 2}

Molecular scanner development: Toward clinical molecular scanner for proteome research: Parallel protein chemical processing before and during western-blot.

Reprinted with permission from Bienvenut, W., Sanchez, J., Karmime, A., Rouge, V., Rose, K., Binz, P., et al. (1999). Toward a clinical molecular scanner for proteome research: parallel protein chemical processing before and during western blot. Anal Chem, 71(21), 4800-4807. Copyright 1999, American Chemical Society.

Abstract

Keywords

120

1. Introduction 121

2. Experimental section $\quad 122$

2.1. Reagents 122

2.2. Covalent attachment of trypsin and blocking of the IAV membrane 122

2.3. Activity measurement of trypsin covalently bound to the IAV membrane

2.4. 1-DE and 2-DE separation 123

2.5. In Gel Digestion 124

2.6. On membrane Digestion $\quad 124$

$\begin{array}{ll}\text { 2.7. OSDT process } & 124\end{array}$

2.8. PIGD 125

2.9. DPD combined method 125

$\begin{array}{ll}\text { 2.10. MALDI-TOF-MS } & 125\end{array}$

2.11. Post-acquisition processing and software identification tools $\quad 126$

3. Results 126

3.1. Activity measurement of trypsin covalently bound to the IAV
membrane

$\begin{array}{lc}\text { 3.2. IGD } & 128\end{array}$

$\begin{array}{lr}\text { 3.3. OMD } & 128\end{array}$

$\begin{array}{ll}\text { 3.4. OSDT } & 129\end{array}$

$\begin{array}{ll}\text { 3.5. PIGD } & 130 \\ 3.6 . \mathrm{DPD} \text { applied to } 1-D E & 130\end{array}$

3.6. DPD applied to 1-DE 130

3.7. Comparative digestion between OSDT, PIGD and the DPD applied to $2-\mathrm{DE}$

3.8. DPD applied to 2-DE 132 
4. Discussion and conclusion 132

5. Acknowledgments 136

$\begin{array}{ll}\text { 6. References } & 136\end{array}$

\section{CHAPTER 3}

Quantitation during electroblotting step: Enhanced protein recovery after electrotransfer using square wave alternating voltage.

Reprint by permission of Elsevier Science from Bienvenut, W., Deon, C., Sanchez, J., \& Hochstrasser, D. (2002). Enhanced protein recovery after electrotransfer using square wave alternating voltage. Anal Biochem, 307(2), 297-303. Copyright 2002.

Abstract

Keywords

1. Introduction

140

2. Material and methods

140

2.1. Mono-dimensional electrophoresis (1-DE) 140

2.2. Electroblot

2.3. Detection, quantification and statistics 142

2.4. $\left[{ }^{14} \mathrm{C}\right]$ signal linearity and influence of the accumulation time 142

3. Results and discussion 143

3.1. Comparison of the electric field and buffer composition effects $\quad 143$

$\begin{array}{ll}\text { 3.2. Statistical test for the transfer reproducibility } & 145\end{array}$

$\begin{array}{ll}\text { 3.3. Gel residual protein after transblotting process } & 146\end{array}$

4. Concluding remarks 148

6. Acknowledgement 149

7. References 149

\section{CHAPTER 4}

Signal traitment and virtual imaging (1/2): A molecular scanner to highly automated research and to display proteome images.

Reprinted with permission from Binz, P., Muller, M., Walther, D., Bienvenut, W., Gras, R., Hoogland, C., et al. (1999). A molecular scanner to automate proteomic research and to display proteome images. Anal Chem, 71(21), 4981-4988. Copyright 1999, American Chemical Society.

Abstract

Keywords

1. Introduction 
xii

2. Experimental section 155

2.1. Materials and reagents 155

2.2. Description of the method 155

3. Results and discussion 158

3.1. Representation of the analysis of a 1-dimensional scan of 1-DE 158

3.2. Representation of the analysis of a two-dimensional scan from a
single band of 1-DE

3.3 Identification by two-dimensional scan of human plasma proteins

4. Discussion 163

5. Conclusion 166

6. Acknowledgement 166

7. References 167

\section{CHAPTER 5}

Signal traitment and virtual imaging (2/2): Visualization and analysis of molecular scanner peptide mass spectra.

Reprint by permission of Elsevier Science from Mueller, M., Gras, R., Appel, R. D., Bienvenut, W. V., \& Hochstrasser, D. F. (2002). Visualization and analysis of molecular scanner peptide mass spectra. J Am Soc Mass Spectrom, 13(3), 221-231. Copyright 2002, by the American Society of Mass Spectrometry.

Abstract

1. Introduction 170

2. Methods 172

3. Results and discussion 173

3.1. Visualization of spectra 173

3.2. Chemical noise 174

3.3. Calibration 176

3.4. Identification and clustering of masses 178

4. Conclusion 185

5. Acknowledgements 187

6. References 187 


\section{CHAPTER 6}

Improvement in the peptide mass fingerprint protein identification (1/2): Hydrogen/deuterium exchange for higher specificity of protein identification by peptide mass fingerprinting

Reprinted by permission of John Wiley \& Sons, Inc., from Bienvenut, W., Hoogland, C., Greco, A., Heller, M., Gasteiger, E., Appel, R., et al. (2002). Hydrogen/deuterium exchange for higher specificity of protein identification by peptide mass fingerprinting. Rapid Commun. Mass Spectrom., 16(6), 616-626. Copyright 2002.

$\begin{array}{lr}\text { Abstract } & 189\end{array}$

1. INTRODUCTION 191

2. Methods 193

2.1. Chemicals 193

2.2. protein separations 193

2.3. In-gel protein digestion 195

2.4. MALDI-ToF MS analysis 195

2.5. H/D exchange on the MALDI sample plate 196

3. Results and discussion 196

3.1. Visualization of spectra 197

3.2. Chemical noise 197

3.3. Calibration 198

3.4. Identification and clustering of masses 199

3.5. Application of the technique to tryptic bovine serum albumin digest 199

3.6. Application of the technique to an unknown protein digest 200

4. Discussion and conclusion $\quad 202$

4.1. Influence of the matrix compound 202

4.2. Influence of the physico-chemical characteristic of the solvent 203

4.3. Influence of the amino acid composition of the peptide 203

4.4. Application of the technique as a validating and discriminating method 204

5. Challenge and future developments 204

6. Acknowledgements 205

7. References 205 


\section{CHAPTER 7}

Improvement in the peptide mass fingerprint protein identification (2/2): MALDI-MS/MS with high resolution and sensitivity for identification and characterization of proteins

Reprinted by permission of Wiley-Liss, Inc, a subsidiary of John Wiley \& Sons, Inc., from Bienvenut, W., Deon, C., Pasquarello, C., Campbell, J., Sanchez, J., Vestal, M., et al. (2002). Matrix-assisted laser desorption/ionization-tandem mass spectrometry with high resolution and sensitivity for identification and characterization of proteins. Proteomics, 2(7), 868-876. Copyright 2002.

Abstract

Keywords

1. Introduction

2. Materials and methods

2.1. Reagents and apparatus

2.2. Protein solubilisation for preparative 2-D PAGE 211

$\begin{array}{ll}\text { 2.3. 2-D PAGE } & 211\end{array}$

2.4. Image analysis $\quad 212$

2.5. Protein digestion $\quad 212$

2.6. Sample preparation $\quad 212$

$\begin{array}{ll}\text { 2.7. Database interrogation } & 214\end{array}$

3. Results 216

3.1. Peptide sequences discrimination 216

$\begin{array}{ll}3.2 . & 218\end{array}$

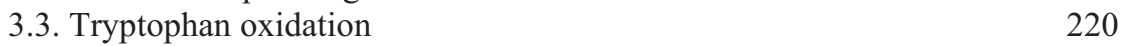

4. Conclusion $\quad 222$

6. Acknowledgements 222

5. References 222

\section{CHAPTER 8}

\section{Proteomic and mass spectrometry: Some aspects and recent developments.}

Bienvenut, W. V., Mueller, M., Palagi, P. M., Gasteiger, E., Heller, M., Jung, E., Giron, M., et al. (2001). Proteomic and mass spectrometry: some aspects and recent developments, In J. N. Housby (Ed.), Mass spectrometry and genomic analysis (1st ed., Vol. 2, pp. 93-145). Dordrecht: Kluwer academic press.

1. Introduction to proteomics

2. Protein biochemical and chemical processing followed by 
$\begin{array}{ll}\text { mass spectrometric analysis } & 226\end{array}$

2.1. 2-DE gel protein separation $\quad 227$

2.2. Protein identification using peptide mass fingerprinting and robots $\quad 229$

$\begin{array}{ll}\text { 2.2.1. MALDI-MS analysis } & 231\end{array}$

$\begin{array}{ll}\text { 2.2.2. MS/MS analysis } & 234\end{array}$

2.2.2.1. MALDI-RETOF-PSD MS analysis $\quad 235$

2.2.2.2. ESI-MS/MS analysis $\quad 236$

2.2.3. Improvement of the identification by chemical modification
of peptides

2.2.3.1. Esterification $\quad 240$

2.2.3.2. H/D exchange: quantitation of labile protons on peptides 241

$\begin{array}{ll}\text { 2.3. The molecular scanner approach } & 247\end{array}$

2.3.1. Double parallel digestion process 247

2.3.2. ${ }^{14} \mathrm{C}$ quantitation of the transferred product and diffusion $\quad 248$

2.3.2.1. Comparison of the influence of the electric field
on the protein recovery

2.3.2.2. DPD quantification test 250

3. Protein identification using bioinformatics tools 252

3.1. Protein identification by PMF tools using MS data 252

3.1.1. Peak detection $\quad 254$

3.1.2. Identification tools $\quad 254$

3.2. MS/MS Ions Search $\quad 259$

$\begin{array}{ll}3.3 \text { De novo sequencing } & 260\end{array}$

3.4 Other tools related to protein identification $\quad 261$

3.5. Data storage and treatment with LIMS 262

$\begin{array}{ll}\text { 3.6. Concluding remarks } & 264\end{array}$

4. Bioinformatics tools for the molecular scanner 265

4.1. Peak detection and spectrum intensity images 265

$\begin{array}{ll}\text { 4.2. Protein identification } & 267\end{array}$

4.3. Validation of identifications $\quad 267$

$\begin{array}{ll}\text { 4.4. Concluding remarks } & 273\end{array}$

$\begin{array}{ll}\text { 5. Conclusion } & 273\end{array}$

6. Acknowledgements 274

$\begin{array}{ll}\text { 7. References } & 274\end{array}$

CHAPTER 9

Conclusions and perspectives

APPENDIX

$\begin{array}{ll}\text { Abbreviations used in this book } & 285\end{array}$

$\begin{array}{ll}\text { Abbreviations for usual amino acids and chemical constants } & 289\end{array}$ 


\section{PREFACE}

Now that the human genome has been fully sequenced, the need for efficient protein analysis and characterization tools has never been so critical. Firstly, computer algorithms have been used to predict genes and it is accepted that as much as $10 \%$ of them might have been missed. Only final gene products, i.e. the proteins, prove that gene sequences with signal sequences, introns and exons are correct. Secondly, it is nearly impossible at present to predict with high accuracy the final polypeptide product and its co- and post-translational modifications. Then, a protein's partial characterization allows a definite identification of the protein's processing such as the amino-acid sequence modification induced by the editing of the mRNA during alternative splicing. Thirdly, there is lack of correlation between the expression levels of mRNA and proteins. Their respective half-lives are very different as well as their levels of expression.

The major difficulty in analysing proteins is the tremendous diversity of their chemical and other properties. Their concentrations vary by more than 12 orders of magnitude in body fluids and by more than 7 orders of magnitude in cells. For example in blood, the concentration of albumin is in the millimolar range and Tnf (tumour necrosis factor) in the femtomolar range. While the $\mathrm{pI}$ (isoelectric point) of DNA or mRNA is around 4.2 to 4.5 , the $\mathrm{pI}$ of proteins extends from less than 3 to more than 12. Whereas the solubility of nucleic acids is excellent, proteins, and especially membrane proteins, can be excessively hydrophobic. Consequently, no single method is available to fully analyse a complex mixture of proteins. In addition, no amplification process such as PCR or RT-PCR exists in the protein world. Therefore, extremely sensitive methods are required to detect the lowabundance proteins.

Many methods to separate, identify and partially characterize polypeptides have been available for a long time. Until recently, many of them required a relatively high concentration/amount of proteins/material. Miniaturization of the analytical techniques does not necessarily solve the difficulty in detecting low-abundance proteins. For example, if in equipment with attomole sensitivity one injects a volume of nanolitres, the limit of detection in concentration does not exceed micromolar, way above the concentration of interesting physiologically relevant proteins. Consequently, the critical step in working with complex protein samples is to select efficient pre-fractionation and separation techniques. Often the best methods are based on affinity pre-purification and a combination of chromatography and/or electrophoresis. Many approaches could be used to detect the proteins and some of their modifications.

Several developments in the field of mass spectrometry offer a new avenue, especially in the area of large-scale protein identification and partial characterization. Multi-compartment equipment allows the precise selection of 
xviii

precursor ions (peptides), their efficient fragmentation and final characterization (sequence and modifications) and can also provide accurate quantification methods. The latest improvements are at both the hardware and software levels to provide fully automated and rapid identification methods.

This book is timely. It reviews in a concise form most techniques that should be known by scientists working in a proteomics laboratory or analysing proteins of interest. It first reviews the electrophoretic and chromatographic separation methods. It then summarizes the quantification and identification methods such as immunoblotting, protein chemistry, peptide fingerprinting or sequencing by fragmentation. Several chapters highlight fascinating developments in the field of mass spectrometry and related techniques. The text shows the reader the perspective of this relatively new field of proteomics.

Finally, the book lists numerous references to critical work done many years ago and unavailable on computer databases. It should therefore be part of every laboratory's library.

Prof. Denis F. HOCHSTRASSER 


\section{ACKNOWLEDGEMENTS}

First of all, I would like to thank all the people, scientists and non-scientists alike, who have contributed to the development of this work. Secondly, I would like to give special thanks to:

- Professor Denis F. Hochstrasser from the Medical University Department of Pathology, Science University at the Department of Pharmacology and responsible for the Clinical Chemistry Central Laboratory at the cantonal hospital of Geneva (Switzerland) for accommodating a research position in his laboratory, thereby improving my knowledge of the chemist's role in protein chemistry, biochemistry and mass spectrometry techniques;

- Dr Jean-Charles Sanchez, responsible for the bi-dimensional electrophoresis laboratory at the cantonal hospital of Geneva for integrating me to his research group and for his critical approach;

- Professor Jean-Luc Veuthey, from Geneva University of Science, responsible for the Pharmacology Section of the Pharmacy and Pharmaceutical Analysis Unit, who accepted the co-direction of my thesis project;

- Professor Jacques Weber, dean of the science faculty, and Dr Jérôme Garin, Research Director at the CEA centre (Grenoble, F), who took time to judge this thesis;

- Véronique Converset, Abderahim Karmime, Gérald Rossellat and Salvo Paesano, technicians at the University Cantonal hospital of Geneva who conducted some of the experiments involved in this project;

- Dr Séverine Frutiger-Hughes from the Pathology Department and Dr Graham Hughes from the Biochemistry Department of the Medical University for their excellent knowledge of protein chemistry and helpful discussions;

- Danièle Roiron head of Prof. Hochstrasser's secretariat, and Dr Catherine Zimmerman from the Clinical Chemistry Central Laboratory at the cantonal hospital of Geneva (Switzerland), for their discussions;

- $\quad$ Professor Keith Rose, Scientific Director of GeneProt (Geneva, CH), for his help in organising my work;

- $\quad$ Professor Darryl Pappin from Applied Biosystems (Framingham, MA, USA) who received me into his laboratory (ICRF, London, UK) and taught me the techniques of peptides chemical modifications;

xix 
- Dr Manfredo Quadroni for his help during the preparation of this manuscript;

Finally, I would like to thank all of the R\&D laboratory as well as personnel from the Clinical Chemistry Central Laboratory for their help over the past 5 years and I address a large thank-you to my parents for all the sacrifices they had to make throughout the years... 


\section{LIST OF CONTRIBUTORS}

Appel Ron D.:

Binz Pierre-Alain:

Campbell Jennifer M.:

Déon Catherine:

Diaz Jean-Jacques:

Gasteiger Elisabeth:

Gays Steven:

Giron Marc:

Gras Robin:

Greco Anna:

Heller Manfred:

Hochstrasser Denis F.:

Hoogland Christine:

Hughes .Graham J.:

Jung Eva E.:
Swiss Institute of Bioinformatics, University Medical Centre, Rue Michel-Servet 1, CH-1211 Geneva 4, Switzerland

Swiss Institute of Bioinformatics, CH-1211 Geneva 14, Switzerland

Applied Biosystems, 500 Old Connecticut Path, Framingham, MA 01701

Central Clinical Chemistry Laboratory, Pathology department, Geneva University Hospital, Rue Michelidu-Crest 24, CH-1211 Geneva 14

INSERM U369, Faculté de Médecine Lyon-R.T.H. Laennec, 7, Rue Guillaume Paradin, 69372 LYON CEDEX 08, France

Swiss Institute of Bioinformatics, University Medical Centre, Rue Michel-Servet 1, CH-1211 Geneva 4, Switzerland

Swiss Institute of Bioinformatics, University Medical Centre, Rue Michel-Servet 1, CH-1211 Geneva 4, Switzerland

Swiss Institute of Bioinformatics, University Medical Centre, Rue Michel-Servet 1, CH-1211 Geneva 4, Switzerland

Swiss Institute of Bioinformatics, University Medical Centre, Rue Michel-Servet 1, CH-1211 Geneva 4, Switzerland

INSERM U369, Faculté de Médecine Lyon-R.T.H. Laennec, 7, Rue Guillaume Paradin, 69372 LYON CEDEX 08, France

Central Clinical Chemistry Laboratory, Geneva University Hospital, CH-1211 Geneva 14, Switzerland

Central Clinical Chemistry Laboratory, Pathology department, Geneva University Hospital, Rue Michelidu-Crest 24, CH-1211 Geneva 14

Swiss Institute of Bioinformatics, University Medical Centre, Rue Michel-Servet 1, CH-1211 Geneva 4, Switzerland

University Medical Centre, Rue Michel-Servet 1, CH1211 Geneva 4, Switzerland

Swiss Institute of Bioinformatics, University Medical Centre, Rue Michel-Servet 1, CH-1211 Geneva 4, Switzerland 
xxii

Karmime Abderahim: Central Clinical Chemistry Laboratory, Geneva

Müller Markus:

University Hospital, CH-1211 Geneva 14, Switzerland

Swiss Institute of Bioinformatics, University Medical

Centre, Rue Michel-Servet 1, CH-1211 Geneva 4,

Switzerland

Palagi Patricia M.: $\quad$ Swiss Institute of Bioinformatics, University Medical Centre, Rue Michel-Servet 1, CH-1211 Geneva 4, Switzerland

Pasquarello Carla: Central Clinical Chemistry Laboratory, Pathology department, Geneva University Hospital, Rue Michelidu-Crest 24, CH-1211 Geneva 14

Rose Keith:

University Medical Centre, Rue Michel-Servet 1, CH1211 Geneva 4, Switzerland

Converset Véronique: (previously Rouge Veronique) Central Clinical Chemistry Laboratory, Geneva University Hospital, CH-1211 Geneva 14, Switzerland

Sanchez Jean-Charles: Central Clinical Chemistry Laboratory, Pathology department, Geneva University Hospital, Rue Michelidu-Crest 24, CH-1211 Geneva 14

Vestal Marvin L.: $\quad$ Applied Biosystems, 500 Old Connecticut Path, Framingham, MA 01701 